Bull. Chem. Soc. Ethiop. 2020, 34(3), 463-469.

ISSN 1011-3924

(C) 2020 Chemical Society of Ethiopia and The Authors

Printed in Ethiopia

DOI: https://dx.doi.org/10.4314/bcse.v34i3.3

\title{
PHOTOCATALYTIC DEGRADATION EFFICIENCY OF AZO DYE IN AQUEOUS PHASE USING DIFFERENT PHOTO CATALYSTS
}

\author{
Nour Abd Alrazzak ${ }^{1}$, Suad T. Saad ${ }^{1}$, Hazim Y. Al-gubury ${ }^{1}$, Mohanad M. Kareem ${ }^{2 *}$ and \\ Mawahib M. Assi ${ }^{1}$ \\ ${ }^{1}$ Department of Chemistry, College of Science for Women, University of Babylon, Hilla, Iraq \\ ${ }^{2}$ Department of Chemistry, College of Science, University of Babylon, Hilla, Iraq
}

(Received August 21, 2019; Revised November 24, 2020; Accepted December 3, 2020)

\begin{abstract}
The new azo dye [4-(4-hydroxy-2-methylnaphthyl)diazenyl]benzoic acid was synthesized by the reaction of 2-methyl-1-naphthol with p-amino benzoic acid. The photcatalytic degradation of azo dye has been investigated by using zinc oxide and cadmium sulfide. This degradation was carried out by the irradiation of aqueous suspended solutions containing different concentrations of this dye using $0.11 \mathrm{~g} / 100 \mathrm{~mL}$ of metal oxide (semiconductors) $\mathrm{ZnO}$ and CdS. A mercury lamp $125 \mathrm{~W}$ in a Pyrex photoreaction cell of $100 \mathrm{~mL}$ at room temperature was used as an irradiation source. The effect of the catalyst on the photocatalytic degradation of the prepared dye was studied via several experiments at different conditions, where they involve the effect of the catalyst mass and the effect of the dye concentrations. The irradiated solutions were studied using UV-Vis spectrophotometer. It has been the performance of photocatalytic system that using $\mathrm{ZnO}$ was observed to be better than cadmium sulfide system for degrade the azo compound from its aqueous solution.
\end{abstract}

KEY WORDS: Photocatalytic, Degradation, Semiconductors, Zinc oxide; Cadmium sulphide, Azo dye

\section{INTRODUCTION}

Azo dyes are more interest field and important type of organic compounds due to their chemical structure which contains the $-\mathrm{N}=\mathrm{N}$ - group that bridges one or more aromatic or heterocyclic systems [1-4]. The synthesis of these dyes is starting with the formation of the diazonium salt which is very important in the organic synthesis [5-7].

Several types of azo dyes are known, and a few classification frameworks exist. A few classes incorporate disperse dyes, metal-complex dyes, reactive and substantive dyes. Moreover called coordinate dyes, substantive dyes are utilized for cellulose-based materials, which incorporate for cotton. The dyes linked to the material by non-electrostatic powers. In another classification, azo colors can be classified agreeing to the number of azo groups [8,9]. In addition, azo dyes are important in pharmaceutical, textile and cosmetics industries. Moreover, these dyes are difficult to be degraded when it is released to water sources [10-12] due to their resistance to light, oxidizing agents and many chemicals.

Many semiconductors such asmetal oxides $\mathrm{ZnO}, \mathrm{TiO}_{2}$ and $\mathrm{CdS}$ are used in photocatalytic degradation to degrade many pollutants such as dyes and heavy metals in wastewater. If the semiconductor is irradiated by UV lamp, the electrons are promoted from the valence band to the conduction band of the semiconducting oxide to give electron-hole pairs. These electrons undergo photo reduction and that leads to leaving a positive hole in the valance band [13].

In addition, zinc oxide as a semiconductor has a wide-band gap, and it is used in many applicable fields due to this band gap, high electron mobility, intensive emission at room temperature and it is transparent. Therefore, it is used in light emitting diodes, electrodes and transistors fabrication [11-14].

In this work $\mathrm{ZnO}$ and $\mathrm{CdS}$ was used as catalysts for photocatalytic degradation process under ultra violet light for a prepared azo dye.

*Corresponding author. E-mail: sci.mohanad.mousa@uobabylon.edu.iq

This work is licensed under the Creative Commons Attribution 4.0 International License 


\section{EXPRIMENTAL}

\section{Apparatus}

The following apparatus were used to characterize the prepared dye. Melting point was measured using SMP30 melting point apparatus. The IR spectra was recorded with a Bruker spectrometer, UV/VIS double beam Spectrophotometer PG CECIL-CE7200 instrument was used to measure the dye solutions optical density. Microelemental analysis was investigated to estimate the content of $\mathrm{C}, \mathrm{H}$ and $\mathrm{N}$ content for the dye using EuroEA3000 Elemental Analyzer, Italy. ${ }^{1} \mathrm{H}-\mathrm{NMR}$ and ${ }^{13} \mathrm{C}$-NMR were recorded on a Bruker AC $400 \mathrm{NMR}$ spectrometer, operating at $400 \mathrm{MHz}$ for ${ }^{1} \mathrm{H}-\mathrm{NMR}$ and $100 \mathrm{MHz}$ for ${ }^{13} \mathrm{C}-\mathrm{NMR}$ at University of Al-albayt, Jordon. All chemical shifts $(\delta)$ are reported in ppm relative to tetramethylsilane (TMS) as reference.

Chemicals

Catalysts and the other chemicals were purchased from Fluka AG and Sigma Aldrich.

Synthesis of [4-(4-hydroxy-2-methylnaphthyl)diazenyl]benzoic acid [14]

A p-amino benzoic acid $(0.01 \mathrm{~mol}, 1.37 \mathrm{~g})$ was dissolved in distilled water $10 \mathrm{~mL}$ and $5 \mathrm{~mL}$ of concentrated $\mathrm{HCl}$ at $0-5{ }^{\circ} \mathrm{C}$. Then $\mathrm{NaNO}_{2}(0.01 \mathrm{~mol}, 0.68 \mathrm{~g})$ was dissolved in distilled water 10 $\mathrm{mL}$ and added as dropwise to the $p$-amino benzoic acid solution for $15 \mathrm{~min}$. This diazonium solution was added dropwise to a mixture of 2-methyl-1-naphthol $(0.01 \mathrm{~mol}, 1.58 \mathrm{~g})$ in absolute ethanol and sodium hydroxide $(1 \mathrm{~g})$ in $10 \mathrm{~mL}$ distilled water. The orange dye precipitate was then filtered and washed with water. Molecular formula: $\mathrm{C}_{18} \mathrm{H}_{14} \mathrm{~N}_{2} \mathrm{O}_{3}$, colour: orange, yield $94 \%$, m.p. $=227-230{ }^{\circ} \mathrm{C} . \mathrm{IR}\left(v, \mathrm{~cm}^{-1}\right): 3391(\mathrm{O}-\mathrm{H}), 2986\left(\mathrm{C}-\mathrm{H}_{\mathrm{Alph}}\right), 3020\left(\mathrm{C}-\mathrm{H}_{\text {Ar.. }}\right), 1681\left(\mathrm{C}=\mathrm{O}_{\text {carboxylic }}\right.$ acid $), 1504(\mathrm{~N}=\mathrm{N}) .{ }^{1} \mathrm{H}-\mathrm{NMR}(\delta, \mathrm{ppm}): 0.9\left(3 \mathrm{H}, \mathrm{CH}_{3}\right), 6.9-8(\mathrm{H}, \mathrm{Ar}-\mathrm{H}), 8.092(\mathrm{H}, \mathrm{Ar}-\mathrm{OH}), 11.2$ $(\mathrm{H}, \mathrm{COOH}) ;{ }^{13} \mathrm{C}-\mathrm{NMR}(\delta, \mathrm{ppm}): 16.0\left(\mathrm{C}, \mathrm{CH}_{3}\right), 116.0-130.0(\mathrm{C}, \mathrm{Ar}-\mathrm{C}), 182.0(\mathrm{C}, \mathrm{C}=\mathrm{O}) . \mathrm{CHN}$ found: C, 70.778; H, 4.62; N 9.21\%; calculated C, 70.588; H 4.575; N, 9.15.

\section{Photoreactor}

All the experiments were done using the photochemical reactor, where its parts have been mentioned in the literature [15].

\section{RESULTS AND DISCUSSION}

\section{Azo dye synthesis}

The azo dye was synthesized by the reaction a diazonium salt of $p$-amino benzoic acid reacted as an electrophile with the nucleophile-coupling compound (2-methyl-1-naphthol) at $\left(0{ }^{\circ} \mathrm{C}\right)$ as shown in Scheme 1.

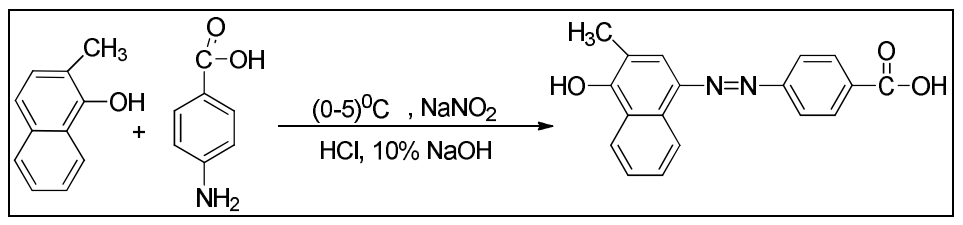

Scheme 1. Azo dye synthesis.

Bull. Chem. Soc. Ethiop. 2020, 34(3) 
Photocatalytic degradation efficiency of azo dye in aqueous phase using different catalysts 465

The IR spectrum of the prepared dye exhibited absorption band of $-\mathrm{N}=\mathrm{N}-$ at $1504 \mathrm{~cm}^{-1}$ and absence of absorption band for $\left(\mathrm{NH}_{2}\right)$ at 3458 and $3359 \mathrm{~cm}^{-1}$ (Figure 1). The ${ }^{1} \mathrm{H}-\mathrm{NMR}$ showed a single signal at $\delta 11.2$ for $(\mathrm{s}, \mathrm{H}, \mathrm{COOH})$ (Figure 2), while the ${ }^{13} \mathrm{C}-\mathrm{NMR}$ showed signal of $(\mathrm{C}$, $\mathrm{COOH})$ at 182 (Figure 3).

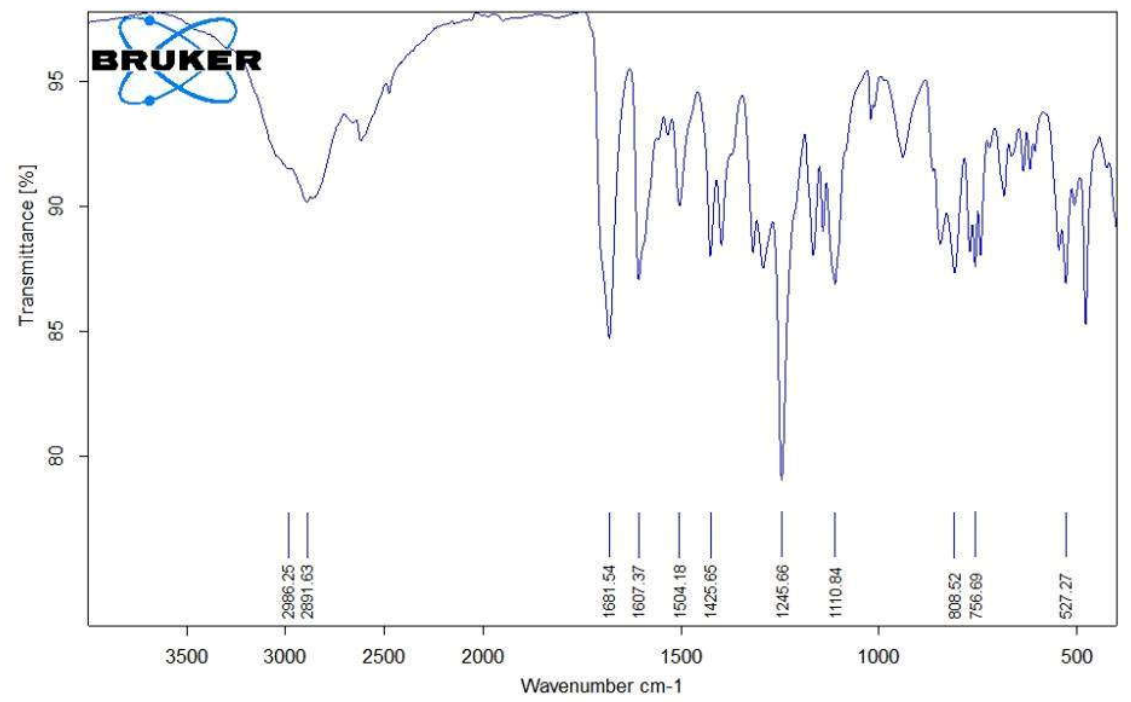

Figure 1. Infrared spectrum of the azo dye.

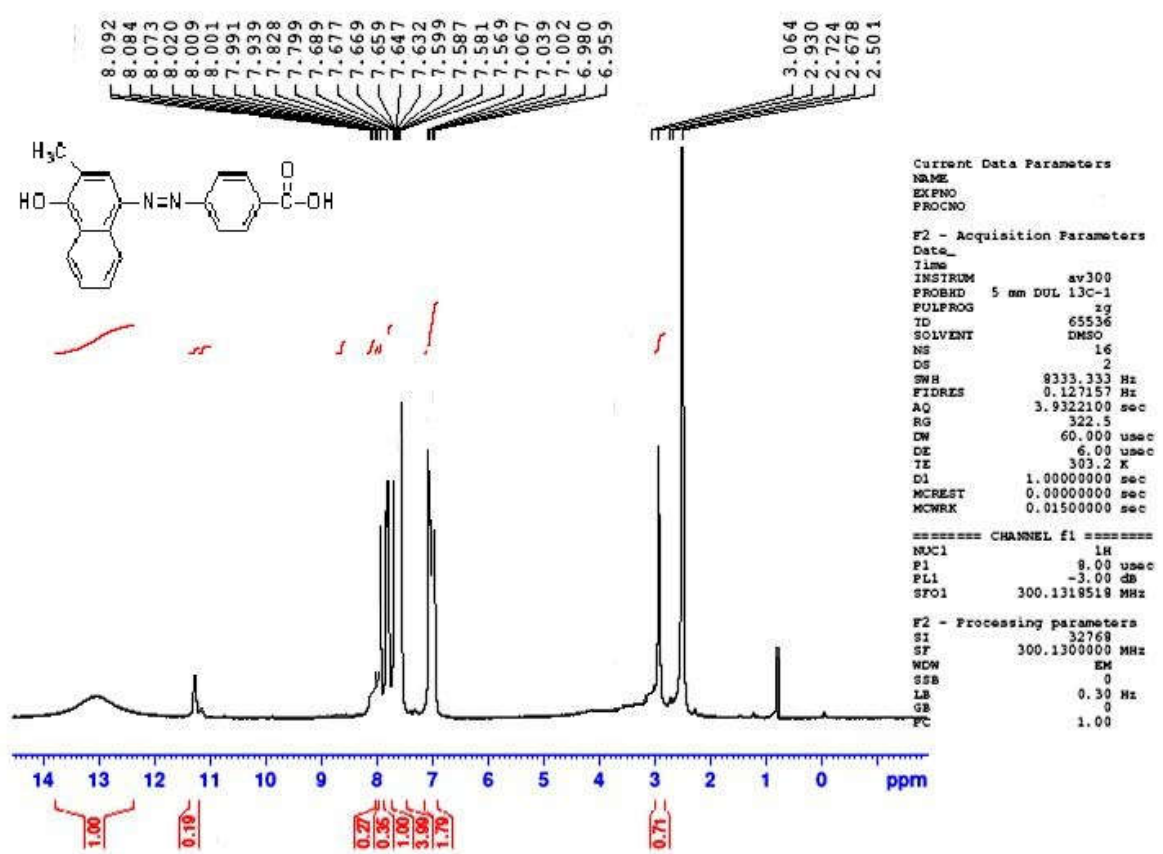

Figure 2. ${ }^{1} \mathrm{H}-\mathrm{NMR}$ of the azo dye.

Bull. Chem. Soc. Ethiop. 2020, 34(3) 

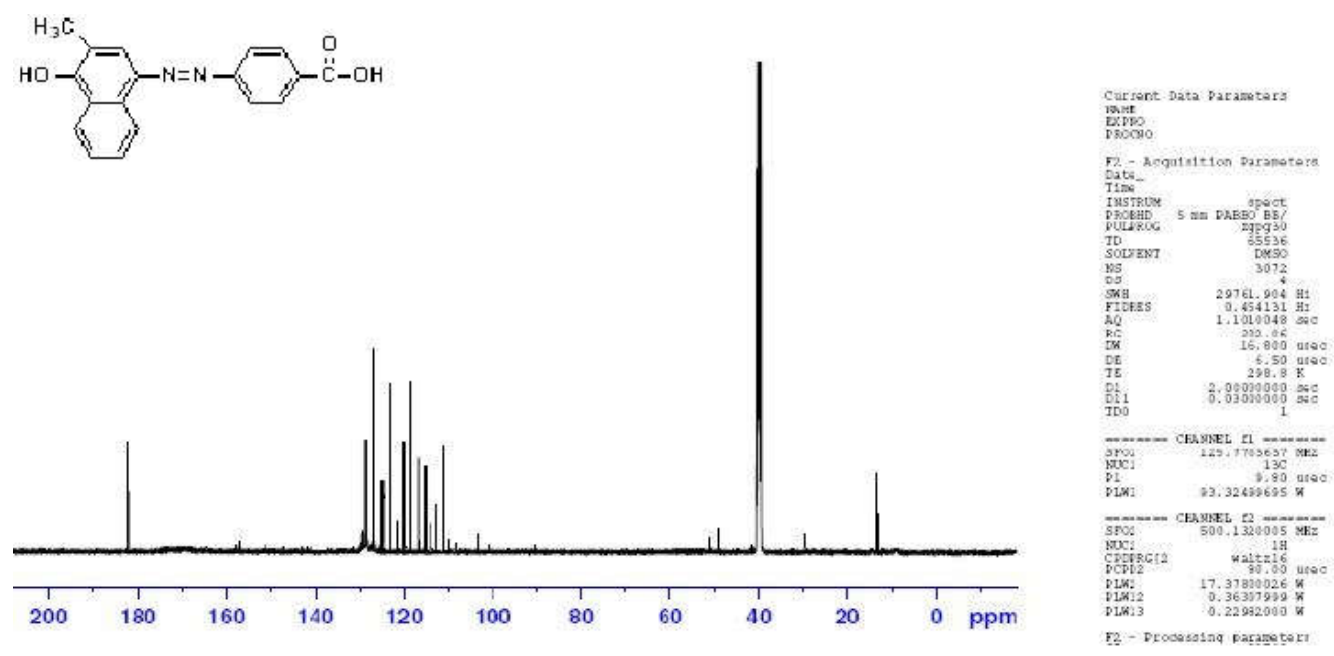

Figure $3 .{ }^{13} \mathrm{C}-\mathrm{NMR}$ spectra of the azo dye.

\section{Effect of $\mathrm{ZnO}$ and CdS masses on photo catalytic degradation of the azo dye}

The effect of the catalysts $\mathrm{ZnO}$ and $\mathrm{CdS}$ masses on the photocatalytic degradation of azo dye was studied using $40 \mathrm{mg} / \mathrm{L}$ of the dye with $10 \mathrm{~mL} / \mathrm{min}$ flow rate of air at room temperature.

As shown in Figure 4, the photocatalytic degradation process of the azo dye at different loaded masses of $\mathrm{ZnO}$ and $\mathrm{CdS}$ gradually increased as the masses of $\mathrm{ZnO}$ and $\mathrm{CdS}$ increased. When the catalysts mass reached $0.11 \mathrm{~g} / 100 \mathrm{~mL}$ the photocatalytic degradation gradually decreased. At this weight, the semiconductors $\mathrm{ZnO}$ and $\mathrm{CdS}$ can provide high light absorption. The less photodegradation efficiency $\mathrm{PDE} \%$ at high masses of the catalysts is due to the light absorption and will be limited only to the first layers of prepared dye. Other layers of solution do not receive light photons $[16,18]$. When the loading masses of catalysts is less than that concentration, the rate of photo degradation of the azo dye also decreased. The reason of that is from the decrease in the catalyst. That means the surface area decreased and that lead to decreasing of light absorption by the catalyst, which caused low photo degradation rate of azo dye. The $\mathrm{ZnO}$ was found to be more efficient than $\mathrm{CdS}$ from the increase in the effective surface area, as shown in Figure 4. However, the percentage of percentage of photocatalytic degradation efficiency (PDE \%) of $\mathrm{ZnO}$ was $92.41 \%$, while that of $\mathrm{CdS}$ was $62.56 \%$ (Figure 5).

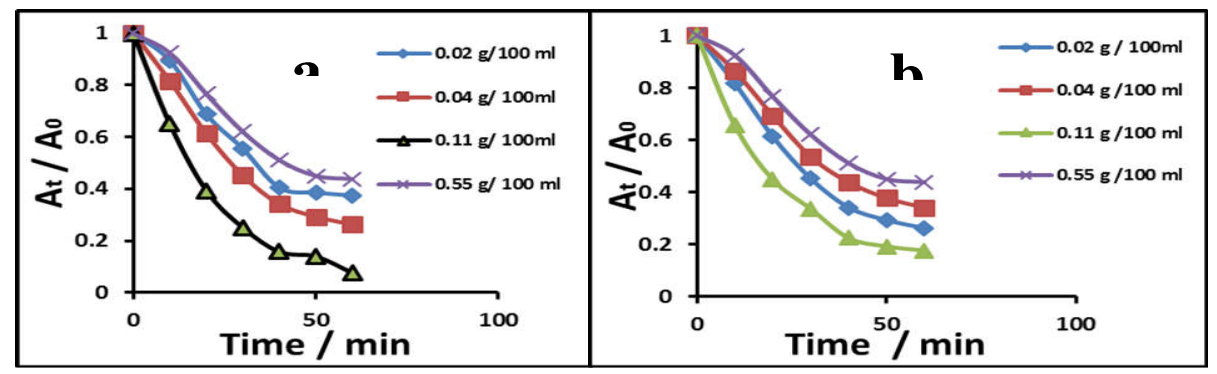

Bull. Chem. Soc. Ethiop. 2020, 34(3) 


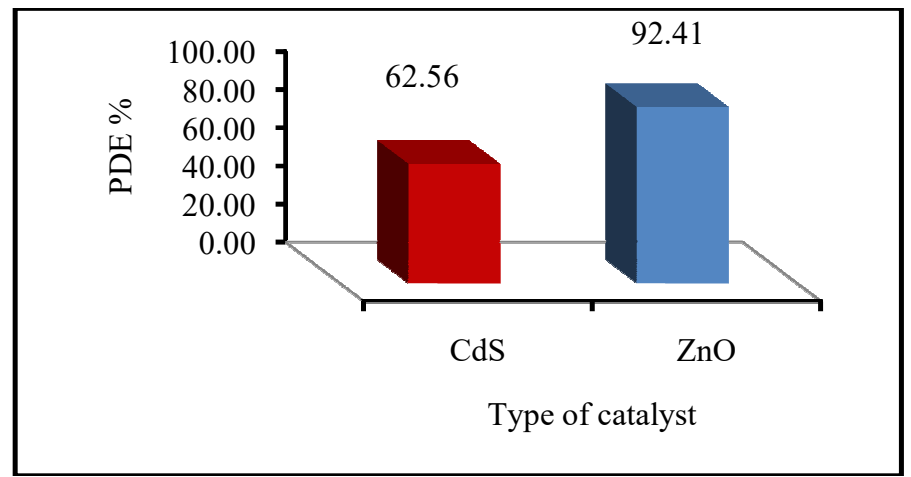

Figure 5. Photocatalytic degradation efficiency (PDE \%) using $\mathrm{ZnO}$ and $\mathrm{CdS}$ with $40 \mathrm{mg} / \mathrm{L}$ of the azo dye.

\section{Photocatalytic degradation process}

The effect of the initial dye concentration on the photocatalytic degradation process was studied using different dye concentrations $40-80 \mathrm{mg} / \mathrm{L}$ with $0.11 \mathrm{~g} / 100 \mathrm{~mL}$ of the catalysts, 8.22 $\mathrm{mW} / \mathrm{cm}^{2}$ light intensity at room temperature. The results are plotted in Figure 6 and it is obvious that the degradation rate gradually decreased when the initial azo dye concentration increased.

The optimum concentration of the dye was $40 \mathrm{mg} / \mathrm{L}$, which it covers the large area of the catalyst. It also was absorbed the largest number of exciting photons to get the higher concentration of the activated catalyst, while the excess of the azo dye prevented the light to go through the other layers of azo dye on the catalyst surface. It was generated the excited photocatalytic degradation efficiency dye state, which it was adsorbed on the catalyst [16]. However, it was found that $\mathrm{ZnO}$ more efficient than $\mathrm{CdS}$, as shown in Figures 6 and 7.
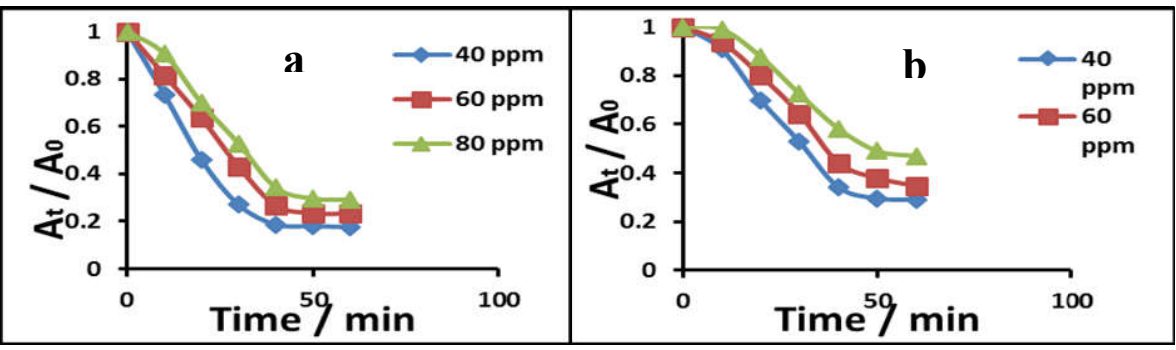

Figure 6. Variation in $\left(\mathrm{A} / \mathrm{A}_{0}\right)$ with irradiation time at different concentrations of the dye with (a) $\mathrm{ZnO}$ and (b) CdS.

A comparison between zinc oxide better than cadmium sulfide as a catalyst on the azo dye degradation was performed using the optimum conditions as $0.11 \mathrm{~g} / 100 \mathrm{~mL}$ of the catalyst with $40 \mathrm{mg} / \mathrm{L}$ of the azo dye. It can be observed that the $\mathrm{ZnO}$ exhibited a higher photocatalytic activity when compared with CdS. This can be attributed to the increase in the effective surface area of the catalyst which led to enhance its photocatalytic activity for the dye degradation. As shown in Figure 8, the photocatalytic degradation efficiency was found to be $95.20 \%$ for $\mathrm{ZnO}$ and $67.40 \%$ for CdS $[18,19]$. 


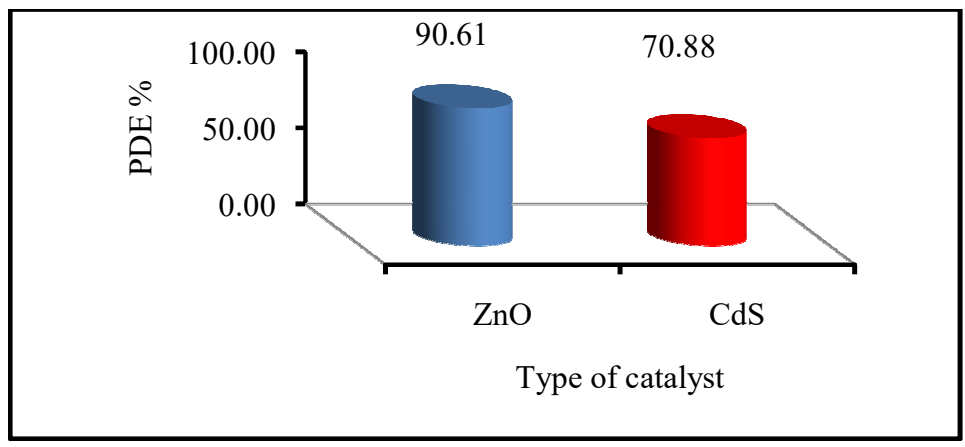

Figure 7. Photocatalytic degradation efficiency (PDE \%) using $0.11 \mathrm{~g} / 100 \mathrm{~mL}$ of each $\mathrm{ZnO}$ and $\mathrm{CdS}$ with $40 \mathrm{mg} / \mathrm{L}$ of the azo dye.

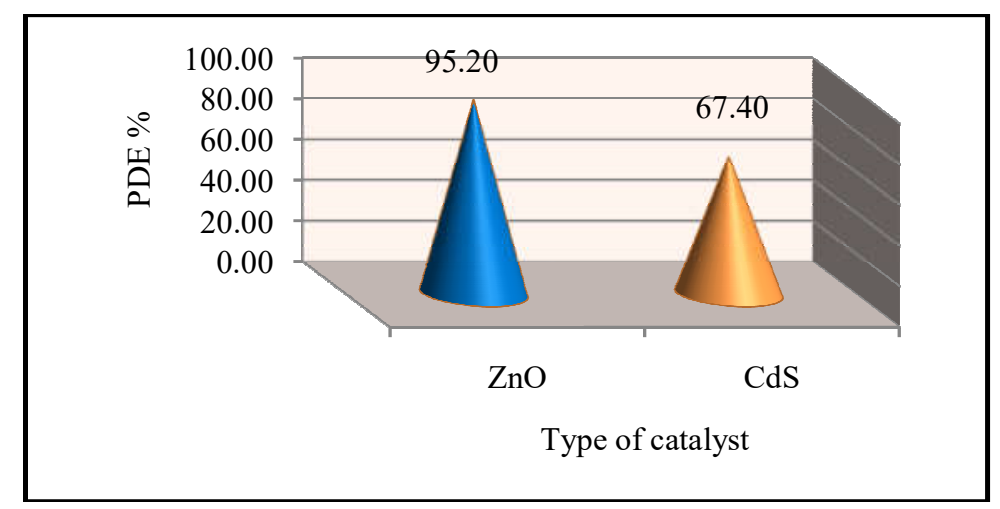

Figure 8. Comparison in photocatalytic degradation efficiency (PDE \%) using $\mathrm{ZnO}$ and $\mathrm{CdS}$ $0.11 \mathrm{~g} / 100 \mathrm{mLof}$ each $\mathrm{ZnO}$ and CdS with $40 \mathrm{mg} / \mathrm{L}$ of the azo dye.

\section{CONCLUSION}

Photocatalytic degradation process under ultra violet light for a prepared azo dye was performed using two catalysts $\mathrm{ZnO}$ and $\mathrm{CdS}$. Several experiments were carried out to reach the optimum conditions for the azo dye degradation. These experiments included the effect of the catalyst mass and the effect of dye concentrations. It was found that $\mathrm{ZnO}$ is more effective than $\mathrm{CdS}$ with 92.41 and $62.56 \mathrm{PDE} \%$, respectively. The effect with the impact of starting dye concentration was found that the photocatalytic degradation productivity utilizing $\mathrm{ZnO}$ was $90.61 \%$ whereas with CdS was $70.88 \%$. In addition, the photocatalytic degradation efficiency was studied under the optimum conditions. It was $95.205 \%$ for $\mathrm{ZnO}$ and $67.40 \%$ for $\mathrm{CdS}$. It could be concluded from this work that the photodegradation of the azo dye using $\mathrm{ZnO}$ is more effective than CdS.

\section{ACKNOWLEDGMENT}

We would like to thank the Department of Chemistry at the College of Science for Women, University of Babylon for providing the support to succeed this work. 
Photocatalytic degradation efficiency of azo dye in aqueous phase using different catalysts 469

\section{REFERENCES}

1. Robert, T.M.; Robert, N.B.; Bhattacharjee, S.K. Organic Chemistry, 6th ed., Pearson Prentice Hall: New Delhi; 2011; pp 1096-1097.

2. Abrahart, E.N. Dyes and Their Intermediate, Chemical Publishing: New York; 1977, pp 112.

3. Bindu, R.L.; Reghunadhan, C.P.; Ninan, K.N. Phenolic resins bearing maleimide groups: Synthesis and characterization. J. Appl. Polym. Chem. 2000, 38, 641-652.

4. Al-janaby, K.M.; AL-Jobory, M.A.M. Synthesis and biological testing of new 1,3oxazepine derivatives of pharmaceutical interest. Karbala J. Pharm. 2014, 5, 21-30.

5. Ameen, S.T.; Khalil, A.I.; Mohammed, A.A. A new method for ISE construction for methyl orange dyes and using for indirect determination of amitriptyline hydrochlorie drug. Baghdad Sci. J. 2015, 12, 188-196.

6. Sudha, M.; Saranya, A.; Selvakumar, G; Sivakumar, N. Microbial degradation of azo dyes: A review. Int. J. Curr. Microbiol. App. Sci. 2014, 3, 670-690.

7. Crini, G. Non-conventional low-cost adsorbents for dye removal: A review. Bioresour. Technol. 2006, 97, 1061-1085.

8. Fosso-Kankeu, E.; Waanders, F.; Geldenhuys, M. Photocatalytic degradation of dyes using $\mathrm{TiO}_{2}$ nanoparticles of different shapes. 7th International Conference on Latest Trends in Engineering \& Technology (ICLTET'2015), Irene, Pretoria (South Africa), November 2627, 2015, pp 84-89.

9. Ahmad, T.; Kandil, F.; Moustapha, C. Preparation and characterization of some new azo dyes, azomethine dyes and heterocyclic Schiff bases derivatives. AASCIT J. Chem. 2015, 2 , 24-31.

10. Gaffer, H.E.; Fouda, M.M.G.; Khalifa, M.E. Synthesis of some novel 2-amino-5arylazothiazole disperse dyes for dyeing polyester fabrics and their antimicrobial activity. Molecules 2016, 21, 122.

11. Wankhede, S.B.; Patil, A.B. Studies on Ti(III), Cr(III) and Fe(III) complexes with 1-(1hydroxynaphthalen-2-yl)ethanone-4-chlorobenzoylhydrazone ligand: Synthesis, Physicochemical and Antimicrobial activity. J. Pharm. Chem. Biol. Sci. 2018, 6, 25-33.

12. Kadhim, M.Y.; Abdulsada, A.M.; Alshawi, M.S. Synthesis, identification and the study of some new azo dyes as corrosion inhibitors for copper in $(1 \mathrm{M}) \mathrm{HCl}$. J. Basrah Res. 2014, 40, 108-127.

13. Jabbar, A.Z.; Hadi, A.G.; Sami, F. Removal of azo dye from aqueous solutions using Chitosan. Oriental J. Chem. 2014, 30, 571-575.

14. Abd Alrazzak, N.; Abdulla, S.; Jassim, A. Synthesis and characterization of new 1,2,4triazole derivatives from 2-naphthol. JUBPAS 2018, 26, 234-252.

15. Al-gubury, H.Y. Study the activity of titanium dioxide nanoparticle using orange $\mathrm{G}$ dye. Malaysian J. Sci. 2016, 35, 319-330.

16. Al-Gubury, H.A.; Mohammed, Q.Y. Prepared coupled $\mathrm{ZnO}-\mathrm{Co}_{2} \mathrm{O}_{3}$ then study the photocatalytic activities using crystal violet dye. JCHPS 2016, 9, 1161-1165.

17. Al-Gubury, H.Y.; Alteemi, H.S.; Saad, A.M.; Al-Shamary, R.R. Removal of hazardous brilliant cresyl blue dye utilizing aluminum oxide as photocatalyst. Indonesian J. Chem. 2019, 19, 292-297.

18. Yadollah, A.; Abdul, H.A.; Zulkarnain, Z. Photodegradation of $o$-Cresol by ZnO under UV irradiation. J. Am. Sci. 2011, 7, 165-170.

19. Krishnakumara, B.; Swaminathan, M. Influence of operational parameters on photocatalytic degradation of a genotoxic azo dye Acid Violet 7 in aqueous $\mathrm{ZnO}$ suspensions. Spectrochim. Acta Part A Mol. Biomol. Spectrosc. 2011, 81, 739-744. 